\title{
Organic anion transporting polypeptide-C mediates arsenic uptake in HEK- 293 cells
}

\author{
Wen-Jen Lu ${ }^{1,2}$, Ikumi Tamai ${ }^{3}$, Jun-ichi Nezu ${ }^{4}$, Ming-Liang Lai ${ }^{5} \&$ Jin-ding Huang ${ }^{1,2,6, *}$ \\ ${ }^{1}$ Institute of Basic Medical Sciences, College of Medicine, National Cheng Kung University, Tainan, Taiwan; \\ ${ }^{2}$ Department of Pharmacology, College of Medicine, National Cheng Kung University, Tainan, Taiwan; \\ ${ }^{3}$ Faculty of Pharmaceutical Sciences, Tokyo University of Science, Noda, Japan; ${ }^{4}$ Chugai Pharmaceutical \\ Co., Ltd., Ibaraki, Japan; ${ }^{5}$ Department of Neurology, College of Medicine, National Cheng Kung University, \\ Tainan, Taiwan; ${ }^{6}$ Department of Pharmacology, Medical College, National Cheng Kung University, 1 \\ University Road, Tainan, 70101, Taiwan
}

Received 21 September 2005; accepted 9 January 2006

(C) 2005 National Science Council, Taipei

Key words: arsenic, OATP-C, transporter

\section{Summary}

Arsenic is an established human carcinogen. The role of aquaglyroporins (AQPs) in arsenic disposition was recently identified. In order to examine whether organic anion transporting polypeptide-C (OATP-C) also plays a role in arsenic transport, OATP-C cDNA was transfected into cells of a human embryonic kidney cell line (HEK-293). Transfection increased uptake of the model OATP-C substrate, estradiol-17 $\beta$-D-glucuronide, by 10 -fold. In addition, we measured uptake and cytotoxicity of arsenate, arsenite, monomethylarsonate $\left(\mathrm{MMA}^{\mathrm{v}}\right)$, and dimethylarsinate $\left(\mathrm{DMA}^{\mathrm{v}}\right)$. Transfection of OATP-C increased uptake and cytotoxicity of arsenate and arsenite, but not of MMA ${ }^{\mathrm{V}}$ or DMA ${ }^{\mathrm{V}}$. Rifampin and taurocholic acid (a substrate of OATP-C) reversed the increased toxicity of arsenate and arsenite seen in OATP-C-transfected cells. The increase in uptake of inorganic arsenic was not as great as that of estradiol-17 $\beta$-D-glucuronide. Our results suggest that OATP-C can transport inorganic arsenic in a (GSH)-dependent manner. However, this may not be the major pathway for arsenic transport.

\section{Introduction}

Several classes of transport systems are involved in hepatic transport of drugs and endogenous substances [1]. In the basolateral membrane of the liver, two major transporter families, the sodiumdependent system and the sodium-independent system, play a key role in uptake of endogenous and exogenous substances from blood [2]. Organic anion transporting polypeptides (OATPs) are membrane solute carriers (SLCs) that are main players in the sodium-independent system. OATPs are known to transport a broad spectrum of

*To whom correspondence should be addressed. Fax: + 886-6274-9296; E-mail: jinding@ms15.hinet.net substrates [3, 4]. OATP-C (or, OATP1B1) is also called OATP-2 or liver-specific transporter 1 (LST-1). It is expressed predominantly at the basolateral membrane of hepatocytes [5]. Substrates of human OATP-C include bromosulfophthalein (BSP), estradiol-17 $\beta$-D-glucuronide $\left(\mathrm{E}_{2} 17 \beta \mathrm{G}\right)$, estrone-3-sulfate, dehydroepiandrosterone sulfate (DHEAS), thyroid hormone, leukotriene $\mathrm{C}_{4}$, rifampin, pravastatin, bile salts, eicosanoids, peptides, and other organic anions [6-10]. OATP-C has also been shown to mediate cellular uptake of bilirubin and its glucuronide conjugates [11].

Arsenic (As) and its derivatives are widely distributed in the environment and exhibit both metallic and nonmetallic properties [12, 13]. It is ubiquitous but toxic, capable of causing acute 
and chronic poisoning. Arsenic is known to cause cancer and vascular disease as well as skin lesions in humans [14-16]. In the US, the Environmental Protection Agency has amended the maximum contaminant level, lowering the standard for arsenic in drinking water from 50 to $10 \mathrm{ppb}$. Interestingly, arsenic trioxide is a good remedy for treating acute promyelocytic leukemia $[17,18]$.

Inorganic trivalent and pentavalent forms of arsenic are the most common oxidation states and are important in causing toxicological problems [19]. It has been generally believed that methylation of inorganic arsenic is a detoxification mechanism $[20,21]$. Most mammals are able to methylate inorganic arsenic to methylarsonic acid $\left(\mathrm{MMA}^{\mathrm{V}}\right)$ and dimethylarsinic acid $\left(\mathrm{DMA}^{\mathrm{V}}\right)$. $\mathrm{DMA}^{\mathrm{V}}$ is the major arsenic metabolite in human urine [22].

Arsenic resistance exhibited by microorganisms is often due to removal of arsenic from the cytosol. Arsenic is effluxed by an arsenite transporter (ArsB) in bacteria and by Acr3p in $S$. cerevisiae. Both transporters are members of the ABC (ATPbinding cassette) family [23, 24]. In eukaryotic organisms, both MRP1 [25, 26] and MRP2 [27] can transport a complex of arsenite and glutathione (GSH). Arsenite and glutathione can form an $\mathrm{As}(\mathrm{GS})_{3}$ complex, in which arsenite is excreted. The route of uptake of arsenic has also been studied. In bacteria, arsenite uptake is facilitated by an aquaglyceroporin (GlpF). In $S$. cerevisiae, the GlpF homolog Fpslp is involved in arsenic uptake. In mammalian cells, the aquaglyceroporins $\mathrm{AQP7}$ and $\mathrm{AQP} 9$ have been shown to uptake arsenite [28, 29].

Glutathione facilitates the function of organic anion transporters. Mercuric conjugates of glutathione are taken up in significant quantities at the basolateral membrane of the renal proximal tubule by an organic anion transport system [30]. Glutathione cis inhibits oatp1-mediated leukotriene $\mathrm{C}_{4}$ and taurocholate uptake [31]. Oatp2 also mediates bidirectional transport of organic anion by a GSH-sensitive facilitative diffusion [32]. Our study examined whether OATP-C can transport arsenic as glutathione conjugates. We measured the uptake of arsenic in control and OATP-C-transfected cells by (ICP-MS), and we used the (MTT) assay to compare the relative cytotoxicity of arsenite, arsenate, $\mathrm{MMA}^{\mathrm{v}}$, and $\mathrm{DMA}^{\mathrm{V}}$ in OATP-C-transfected and control cells.

\section{Materials and methods}

\section{Materials}

$\left[{ }^{3} \mathrm{H}\right] \quad$ estradiol-17 $\beta$-D-glucuronide $\quad\left(\mathrm{E}_{2} 17 \beta \mathrm{G}\right.$; $1.67 \mathrm{TBq} / \mathrm{mmol})$ and $\left[{ }^{3} \mathrm{H}\right]$ taurocholic acid $(130 \mathrm{GBq} / \mathrm{mmol})$ were purchased from Perkin Elmer Life Sciences (Boston, MA). Monosodium acid methane arsonate $\left(\mathrm{CH}_{4} \mathrm{AsNaO}_{3} \cdot 1.5 \mathrm{H}_{2} \mathrm{O}\right)$ was obtained from Supelco (Bellefonte, PA). Dimethylarsinic acid sodium salt trihydrate $\left(\left(\mathrm{CH}_{3}\right)_{2} \mathrm{AsO} \mathrm{O}_{2} \mathrm{Na}\right)$ was obtained from Merck (Hohenbrunn, Germany). Sodium arsenate, sodium arsenite, and (MTT) were purchased from Sigma Chemical Co. (Steinheim, Germany). Geneticin (G418) was obtained from Gibco (Grand Island, $\mathrm{NY}$ ). ImmobilonTM transfer membrane was purchased from Millipore (Bedford, MA). Goat antirabbit IgG-horseradish peroxidase (HRP) was purchased from Santa Cruz Biotechnology (Santa Cruz, CA). Human liver-specific transporter (LST1) antibody was purchased from Alpha Diagnostic (San Antonio, TX).

\section{Cell culture and stable cell line selection}

HEK-293 cells were obtained from the Food Industry Research and Development Institute (FIRDI, Hsinchu, Taiwan). HEK-293 cells were cultured in minimum essential medium (Gibco) containing $10 \%$ horse serum at $37^{\circ} \mathrm{C}$ and $5 \%$ $\mathrm{CO}_{2}$. The parental vector pcDNA3 or the constructs (pcDNA3- OATP-C) were transfected into HEK-293 cells using the calcium phosphate precipitation method. After transfection, cells were selected with $600 \mu \mathrm{g} / \mathrm{ml}$ G418 for two weeks. G418-resistant colonies were screened by transport study and immunoblot analysis.

\section{Reverse-transcriptase ( $R T)$ - $P C R$ analysis of OATP-C IRNA expression}

Total RNA was extracted from HEK-OATP-C and HEK-Co cells using the Ultraspec ${ }^{\mathrm{II}} \mathrm{Kit}$ (Biotecx Laboratories, Inc., Texas). A 2- $\mu \mathrm{g}$ portion was primed with oligo-dT and reversetranscribed using Superscript II reverse transcriptase (Gibco). Primers for amplification of OATP-C cDNA were as follows: OATP-C-F: $5^{\prime}$ TGC ACTT GAG GCA CCT CAC-3' (sense) and OATP-C-R: 5'-CTT CAT CCA TGA CAC TTC 
CAT TT-3' (antisense). PCR cycling conditions were as follows: $5 \mathrm{~min}$ denaturation at $95^{\circ} \mathrm{C}$; 30 cycles of $30 \mathrm{~s}$ at $95{ }^{\circ} \mathrm{C}, 30 \mathrm{~s}$ at $55^{\circ} \mathrm{C}, 30 \mathrm{~s}$ at $72{ }^{\circ} \mathrm{C} ; 7 \mathrm{~min}$ final elongation at $72{ }^{\circ} \mathrm{C}$. RT-PCR products were resolved on a $1.5 \%$ agarose gel at $100 \mathrm{~V}$ at $45 \mathrm{~min}$, followed by staining with ethidium bromide and visualized by ultraviolet illumination. A 359-bp fragment of OATP-C cDNA was amplified using specific primers.

\section{Preparation of crude membrane fractions}

Crude HEK-293 membrane was prepared with published methods [33]. Cells were disrupted by sonication in hypotonic buffer $(20 \mathrm{mM}$ HEPES pH7.2, $3 \mathrm{mM} \mathrm{KCl}, 3 \mathrm{mM} \mathrm{MgCl} 2$ ). After centrifugation $\left(100,000 \mathrm{~g} ; 4{ }^{\circ} \mathrm{C} ; 45 \mathrm{~min}\right)$ pellets were resuspended in Tris buffer $(50 \mathrm{mM}$; $\mathrm{pH} 7.4)$. Crude membrane fractions were stored at $-70^{\circ} \mathrm{C}$ before being used for Western blot analysis. All membranes were prepared in the presence of protease inhibitors (aprotinin $10 \mathrm{~g} / \mathrm{ml}$, leupeptin $10 \mu \mathrm{g} / \mathrm{ml}$, $1 \mathrm{mM}$ phenylmethylsulfonyl fluoride); all procedures were performed at $0-4{ }^{\circ} \mathrm{C}$. The membrane protein concentration was determined by (BCA) assay with bovine serum albumin (BSA) as standard.

\section{Immunoblot analysis}

For Western blot analysis, crude membrane proteins $(50 \mu \mathrm{g})$ were diluted with sample buffer and incubated at $37^{\circ} \mathrm{C}$ for $30 \mathrm{~min}$ before separation on $8 \%$ resolving sodium dodecylsulfate (SDS)polyacrylamide gels, followed by electrophoretic transfer to PVDF membrane (Millipore) for $90 \mathrm{~min}$. Then, the membrane was blocked in 5\% BSA in TBS-T (20 mM Tris- $\mathrm{HCl}, \mathrm{pH} 7.6,137 \mathrm{mM}$ $\mathrm{NaCl}, 0.1 \%$ Tween 20 ) for $1 \mathrm{~h}$ at room temperature. This was followed by incubation with 200-fold diluted anti-OATP-C rabbit serum (LST-1) in 2.5\% BSA in TBS-T overnight at $4{ }^{\circ} \mathrm{C}$. After five washes with TBS-T, the membrane was incubated with 3000-fold diluted goat anti-rabbit IgG-HRP for $60 \mathrm{~min}$ followed by another five washes with TBS-T. Signals were detected using ECL $^{\mathrm{TM}}$ Western Blotting Detection Reagents (Amersham Biosciences, Inc., Taiwan).

\section{Uptake transport assays}

HEK-293 stable cell lines (pcDNA3 or pcDNA3OATP-C) were seeded in six-well dishes. After $72 \mathrm{~h}$, experiments were initiated by gently removing medium and adding $1 \mathrm{ml}$ transport medium (optiMEM; Invitrogen) containing radiolabeled $\operatorname{drug}\left(\left[{ }^{3} \mathrm{H}\right] \mathrm{E}_{2} 17 \beta \mathrm{G}(0.2 \mathrm{Ci} / \mathrm{ml})\right.$ or $\left[{ }^{3} \mathrm{H}\right]$ taurocholic acid $(1 \mathrm{Ci} / \mathrm{ml}))$ in the presence or absence of various inhibitors for $30 \mathrm{~min}$ at $37{ }^{\circ} \mathrm{C}$. At the experiment's end, cells were washed with ice-cold phosphate buffered saline (PBS) and lysed with $1 \mathrm{ml} 1 \%$ SDS. Retained cellular radioactivity was quantified by liquid scintillation spectrometry. Protein concentration was determined with a BCA assay using 101 cell lysate.

\section{Cytotoxicity assay}

The cytotoxicity of arsenic to HEK-293 cells was determined using the MTT (3-(4,5-dimethylthiazol2-yl)-2,5-diphenyltetrazolium bromide) assay. In brief, OATP-C-transfected and control (transfected with pcDNA3) cells were seeded in 96-well dishes at a density of $1 \times 10^{4}$ cells per well. After 24 $\mathrm{h}$ incubation, cells were treated with various concentrations of arsenic in the presence or absence of rifampin or taurocholic acid. After 72-h incubation, $40 \mu \mathrm{MTT}(2.5 \mathrm{mg} / \mathrm{ml})$ was added per well. Cells were incubated in a $\mathrm{CO}_{2}$ incubator at $37{ }^{\circ} \mathrm{C}$ for $4 \mathrm{~h}$. After gently decanting supernatant and adding $1001 \mathrm{DMSO}$ to each well, the pellet was resuspended for $30 \mathrm{~min}$ at $37^{\circ} \mathrm{C}$. Optical density was then measured at $570 \mathrm{~nm}$.

\section{Measurement of intracellular arsenic}

Control and OATP-C-transfected cells were plated on a $10-\mathrm{cm}$ culture dish and grown to $90 \%$ confluence in culture medium. Cells were treated with various concentrations of arsenic for $1 \mathrm{~h}$. At the end of treatment, cells were washed with PBS and lysed with $1 \mathrm{ml} \quad 0.5 \%$ NP-40. The lysis solution were digested by $2 \mathrm{ml}$ nitric acid for $4 \mathrm{~h}$ and then diluted with $3 \mathrm{ml} \mathrm{MQ}$. Total arsenic concentration was determined by inductively coupled argon mass spectrometry (ICP-MS) and normalized with cellular protein. 


\section{Synthesis of $\mathrm{As}(\mathrm{GS})_{3}$}

Arsenic triglutathione (ATG) was prepared as described previously by Kala et al. [27] with modifications. ATG was prepared by dissolving sodium arsenite $(0.0129 \mathrm{~g} ; 0.1 \mathrm{mmol})$ and GSH $(0.0921 \mathrm{~g} ; 0.3 \mathrm{mmol})$ in $1 \mathrm{ml} \mathrm{MQ}$; the reaction was carried out for $12 \mathrm{~h}$ at room temperature. Then, the $\mathrm{As}(\mathrm{GS})_{3}$ complex was precipitated with $4 \mathrm{ml}$ methanol and the precipitate was filtered and residual water removed under reduced pressure.

$A S^{I I I}$ and $\mathrm{As}(\mathrm{GS})_{3}$ transport studies

Control and OATP-C-transfected cells were harvested and suspended in KRH buffer containing $120 \mathrm{mM} \mathrm{NaCl}, 4.7 \mathrm{mM} \mathrm{KCl}, 10 \mathrm{mM}$ D-glucose, $2.2 \mathrm{mM} \mathrm{CaCl}_{2}, 1.2 \mathrm{mM} \mathrm{KH}_{2} \mathrm{PO}_{4}, 1.2 \mathrm{mM} \mathrm{MgSO}_{4}$ and $25 \mathrm{mM}$ HEPES (pH 7.4). Uptake was initiated after cells were added $10 \mu \mathrm{M} \mathrm{As}^{\mathrm{III}}$ or $\mathrm{As}(\mathrm{GS})_{3}$ and incubated with $\mathrm{KRH}$ buffer at $37{ }^{\circ} \mathrm{C}$ for $1 \mathrm{~h}$. At the end of the experiment, cells were washed with PBS and lysed with $1 \mathrm{ml} 0.5 \%$ NP-40. The lysis solution were digested by $2 \mathrm{ml}$ nitric acid for $4 \mathrm{~h}$ and then diluted with $3 \mathrm{ml} \mathrm{MQ}$. Total arsenic concentration was determined by ICP-MS.

\section{Data analysis}

$\mathrm{LC}_{50}$ values of cytotoxicity were estimated by Scientist software (MicroMath Inc., Salt Lake City, UT). LC $_{50}$ values of different cell lines were compared using Student's $t$-test.

\section{Results}

Expression of OATP-C in HEK-293 cells

HEK-293 cells were stably transfected with vector constructs containing human OATP-C and parental vector pcDNA3. G418-resistant clones were screened for OATP-C expression by immunoblot analysis and RT-PCR assay. As shown in Figure 1a, membrane vesicles prepared from HEK-293 transfectants were immunoblotted using polyclonal antibody LST-1, which recognizes the carboxyl terminus of human OATP-C. OATP-C showed an apparent molecular mass of about $90 \mathrm{kDa}$, the same as found in human liver [34].
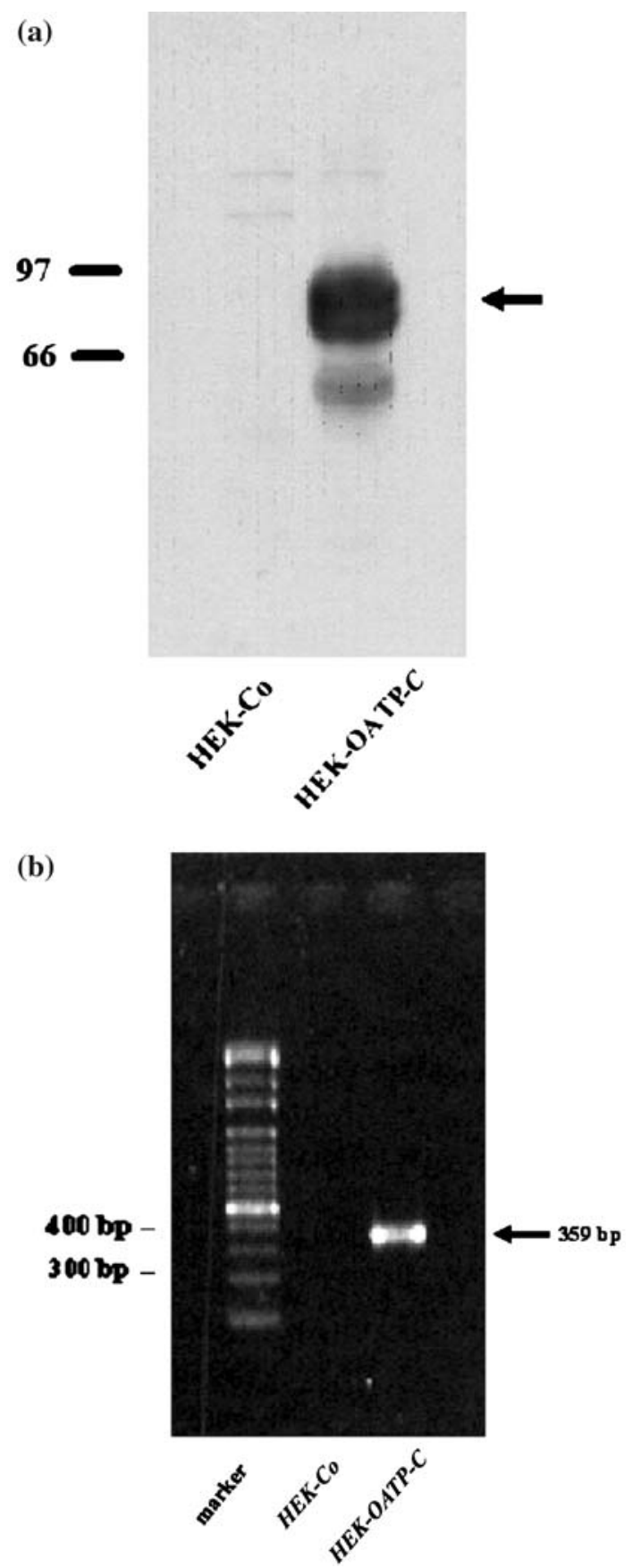

Figure 1. Immunoblot and RT-PCR analysis of HEK-293 cells stable transfected with OATP-C. (a) Membrane fractions from cells $(50 \mu \mathrm{g})$ transfected with OATP-C (HEK-OATP-C) or vector (HEK-Co). OATP-C was detected by the polyclonal antibody LST-1. (b) RT-PCR analysis of OATP-C mRNA expression.

Expression of OATP-C was further confirmed by RT-PCR analysis as shown in Figure 1b. Only a 359-bp cDNA fragment was detected in OATP-C- 

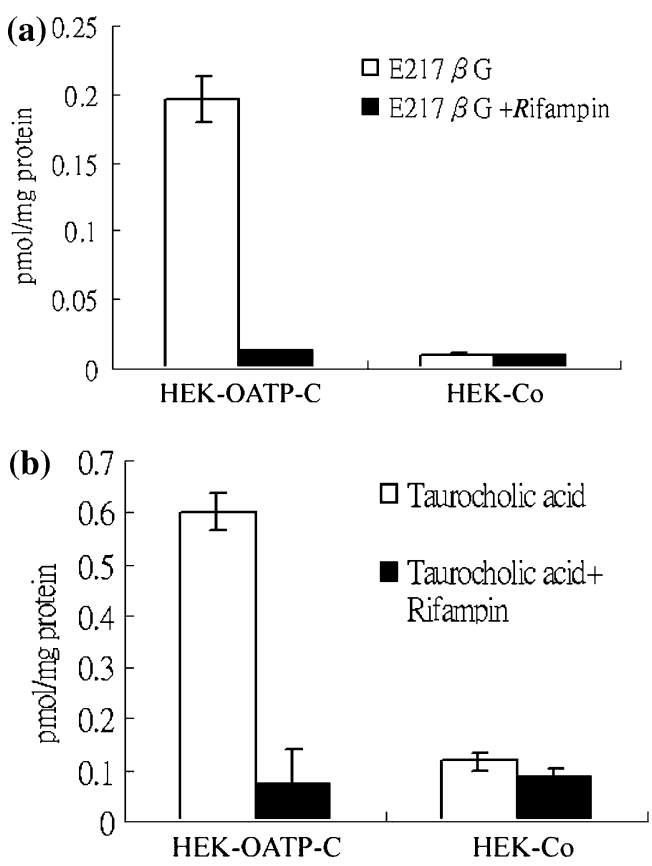

Figure 2. Uptake of $\left[{ }^{3} \mathrm{H}\right]$-Estradiol-17 $\beta$-D-glcuronide (a) and $\left[{ }^{3} \mathrm{H}\right]$ taurocholic acid (b) in HEK-Co (pcDNA3) or HEKOATP-C cells. Data are the mean $\pm \mathrm{SD}$ of triplicate determinations.

transfected (HEK-OATP-C) cells using primers specifically for OATP-C. In vector-transfected (HEK-Co) cells, no signal was detected.

Uptake study in OATP-C-expressing HEK-293 cells

HEK-OATP-C and HEK-Co cells were assayed for uptake of $\left[{ }^{3} \mathrm{H}\right] \mathrm{E}_{2} 17 \beta \mathrm{G}$ and $\left[{ }^{3} \mathrm{H}\right]$ taurocholic acid. Uptake of $\left[{ }^{3} \mathrm{H}\right] \mathrm{E}_{2} 17 \beta \mathrm{G}$ or $\left[{ }^{3} \mathrm{H}\right]$ taurocholic acid into HEK-OATP-C cells and HEK-Co cells are shown in Figure 2. Uptake of either compound into HEK-OATP-C cells was 10 times higher than into HEK-Co cells. In HEK-OATP-C cells, uptake of $\left[{ }^{3} \mathrm{H}\right] \mathrm{E}_{2} 17 \beta \mathrm{G}$ was reduced to the level seen in HEK-Co cells when the experiment was run with $100 \mu \mathrm{M}$ rifampin (substrate of OATP-C) (Figure 2a). OATP-C-mediated uptake of $\left[{ }^{3} \mathrm{H}\right]$ taurocholic acid was also inhibited by $100 \mu \mathrm{M}$ rifampin (Figure 2b).

Uptake of $A s^{I I I}, A s^{V}, M M A^{V}$ and $D M A^{V}$

After an uptake assay was used to study whether OATP-C could transport arsenic, uptake of As ${ }^{\text {III }}$, $\mathrm{As}^{\mathrm{V}}, \mathrm{MMA}^{\mathrm{V}}$, and DMA ${ }^{\mathrm{v}}$ in HEK-Co and HEK-

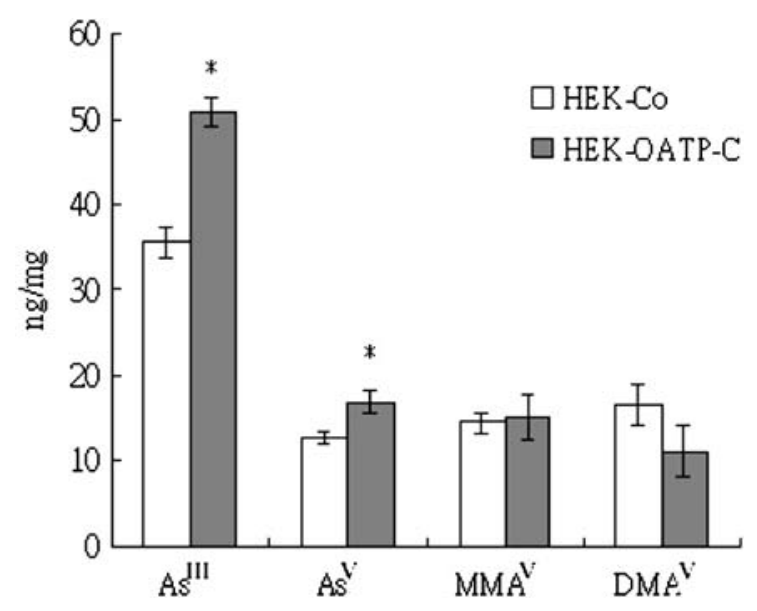

Figure 3. Accumulation of arsenic compounds in HEK-Co and HEK-OATP-C cells. Cells were incubated with $10 \mu \mathrm{M}$ various arsenic for $1 \mathrm{~h}$, and then intracellular arsenic was determined by ICP-MS as described in Materials and methods. The results are shown as mean $\pm \mathrm{SD}(n=3) .{ }^{*} p<0.05$, significantly different from HEK-Co.

Table 1. $\mathrm{LC}_{50}(\mu \mathrm{M})$ of arsenic compunds in control and OATP-C transfected cells.

\begin{tabular}{lll}
\hline & Control & OATP-C \\
\hline $\mathrm{As}^{\mathrm{III}}$ & $10.9 \pm 0.9$ & $5.6 \pm 0.1^{*}$ \\
$\mathrm{As}^{\mathrm{V}}$ & $98.1 \pm 3.2$ & $53.0 \pm 1.2^{*}$ \\
$\mathrm{MMA}^{\mathrm{V}}$ & $4319.3 \pm 618.7$ & $4211.6 \pm 387.4$ \\
$\mathrm{DMA}^{\mathrm{V}}$ & $994.1 \pm 49.9$ & $899.3 \pm 61.2$ \\
\hline
\end{tabular}

Values are mean \pm SD for quadruplicate experiments. ${ }^{*} p<0.05$.

OATP-C cells were determined by ICP-MS. Values for both cell types are shown in Figure 3. Values of intracellular $\mathrm{As}^{\mathrm{III}}$ and $\mathrm{As}^{\mathrm{V}}$ in HEKOATP-C cells were $50.81 \pm 1.64$ and $16.99 \pm$ $1.31 \mathrm{ng} / \mathrm{mg}$, respectively, and in HEK-Co cells the values were $35.60 \pm 1.79$ and $12.64 \pm 0.68 \mathrm{ng} /$ $\mathrm{mg}$, respectively. However, there was no statistical difference in uptake values of $\mathrm{MMA}^{\mathrm{V}}$ and $\mathrm{DMA}^{\mathrm{V}}$ between HEK-Co cells $(14.49 \pm 1.30$ and $16.53 \pm$ $2.39 \mathrm{ng} / \mathrm{mg}$, respectively) and HEK-OATP-C cells $(15.16 \pm 2.68$ and $11.05 \pm 2.92 \mathrm{ng} / \mathrm{mg}$, respectively).

Cytotoxicity of $A s^{I I I}, A s^{V}, M M A^{V}$, and $D M A^{V}$

After analyzing arsenic uptake data, which showed that OATP-C increased uptake of $\mathrm{As}^{\mathrm{III}}$ and $\mathrm{As} \mathrm{v}^{\mathrm{V}}$, we used MTT assays to further clarify the role of OATP-C in arsenic transport. Table 1 shows the 
(a) $\mathrm{As}^{\mathrm{III}}+50 \mu \mathrm{M}$ Rifampin

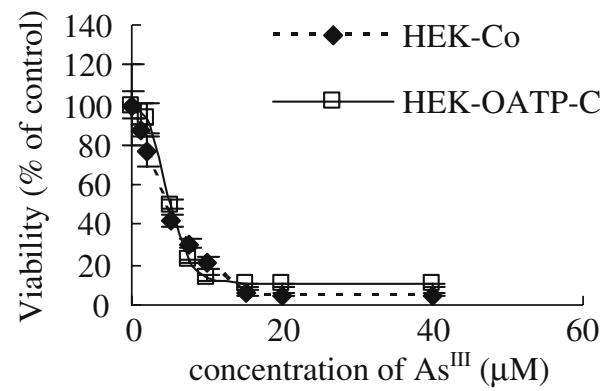

(c) $\mathrm{As}^{\mathrm{v}}+50 \mu \mathrm{M}$ Rifampin

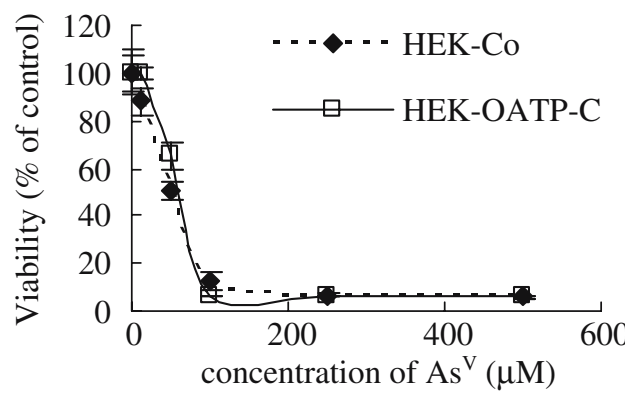

(b) $\mathrm{As}^{\mathrm{III}}+500 \mu \mathrm{M}$ Taurocholic acid

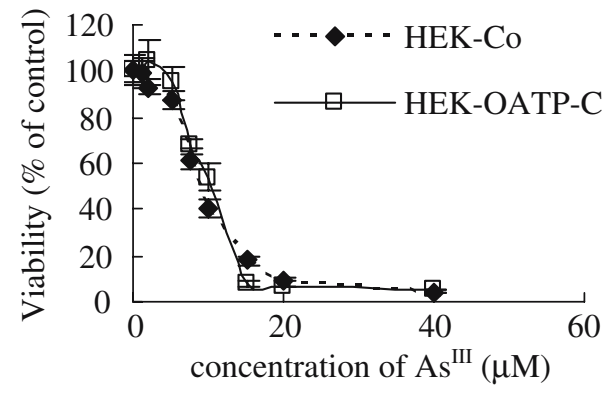

(d) $\mathrm{As}^{\mathrm{v}}+500 \mu \mathrm{M}$ Taurocholic acid

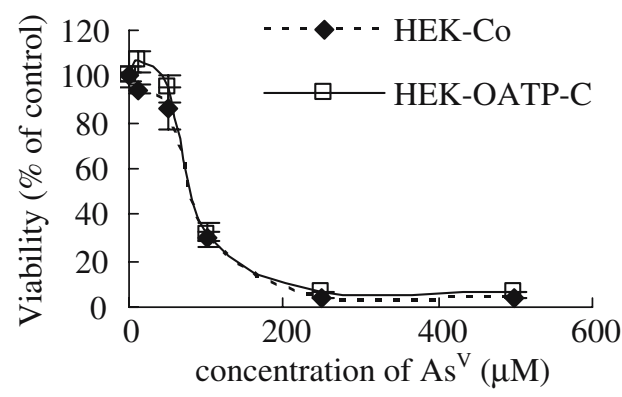

Figure 4. Effects on arsenic cytotoxicity by rifampin or taurocholic acid in HEK-Co or HEK-OATP-C cells. The cells were treated with various concentrations of $\mathrm{As}{ }^{\mathrm{III}}$ with $50 \mu \mathrm{M}$ rifampin (a) or $500 \mu \mathrm{M}$ taurocholic acid (b), and $\mathrm{As}{ }^{\mathrm{V}}$ with $50 \mu \mathrm{M}$ rifampin (c) or $500 \mu \mathrm{M}$ taurocholic acid (d). The cytotoxicity was determined by MTT assay. Data are the mean \pm SD of quadruplicate determinations.

dose-related cytotoxicity of $\mathrm{As}^{\mathrm{III}}, \mathrm{As}^{\mathrm{v}}, \mathrm{MMA}^{\mathrm{V}}$, and DMA ${ }^{\mathrm{V}}$ in HEK-OATP-C and HEK-Co cells. $\mathrm{LC}_{50}$ values for $\mathrm{As}^{\mathrm{III}}, \mathrm{As}^{\mathrm{V}}, \mathrm{MMA}^{\mathrm{V}}$, and $\mathrm{DMA}^{\mathrm{V}}$ in HEK-Co cells were calculated to be $10.9 \pm 0.9$, $98.1 \pm 3.2, \quad 4319.3 \pm 618.7$, and $994.1 \pm 49.9 \mu \mathrm{M}$, respectively; in HEK-OATP-C cells, the values were $5.6 \pm 0.1, \quad 53.0 \pm 1.2, \quad 4211.6 \pm 387.4$ and $899.3 \pm 61.2 \mu \mathrm{M}$, respectively. Cytotoxicity of $\mathrm{As}^{\mathrm{III}}$ and $\mathrm{As} \mathrm{v}^{\mathrm{V}}$ were greater in HEK-OATP-C cells than in HEK-Co cells, but there was no difference in $\mathrm{MMA}^{\mathrm{V}}$ and $\mathrm{DMA}^{\mathrm{V}}$ cytotoxicity between cell types. To confirm whether the difference in arsenic cytotoxicity between HEK-OATP-C and HEK-Co cells was caused by the OATP-C transporter, cells were treated with OATP-C substrates $(50 \mu \mathrm{M}$ rifampin or $500 \mu \mathrm{M}$ taurocholic acid). Rifampin or taurocholic acid reversed the difference between HEK-OATP-C and HEK-Co cells regarding As ${ }^{\text {III }}$ and $\mathrm{As}^{\mathrm{V}}$ cytotoxicity (Figure 4). $\mathrm{LC}_{50}$ values of As ${ }^{\text {III }}$ plus rifampin or taurocholic acid in HEK-Co cells were $4.8 \pm 1.1$ and $9.2 \pm 1.0 \mu \mathrm{M}$, respectively, and in HEK-OATP-C cells the values were
$4.9 \pm 1.0$ and $9.4 \pm 1.0 \mu \mathrm{M}$, respectively. On the other hand, the values for $\mathrm{As}^{\mathrm{V}}$ plus rifampin or taurocholic acid in HEK-Co cells were calculated to be $52.3 \pm 1.0$, and $84.8 \pm 1.1 \mu \mathrm{M}$, respectively; in HEK-OATP-C cells, the values were $53.4 \pm 1.1$ and $85.3 \pm 1.2 \mu \mathrm{M}$, respectively.

Uptake of $\mathrm{As}(\mathrm{GS})_{3}$ by HEK-OATP-C cells

Although results of uptake and cytotoxicity assays indicated that OATP-C could transport inorganic arsenic, it was unclear whether OATP-C transported inorganic arsenic only or inorganic arsenicthiol compounds. Therefore, we studied whether $\mathrm{As}^{\mathrm{III}}$ or $\mathrm{As}(\mathrm{GS})_{3}$ was a substrate for OATP-C. Cells were resuspended in KRH buffer, and then uptake of $\mathrm{As}^{\mathrm{III}}$ or $\mathrm{As}(\mathrm{GS})_{3}$ by OATP-C was determined. In Figure 5, $\mathrm{As}(\mathrm{GS})_{3}$ uptake was higher in HEK-OATP-C cells than in HEK-Co cells. However, there was no difference in $\mathrm{As}^{\mathrm{III}}$ uptake between HEK-Co and HEK-OATP-C cells. 


\section{Discussion}

Arsenic is widely distributed in the environment and its toxicity is a major public health problem. Generally, most arsenic in drinking water is inorganic. Inorganic arsenic is absorbed by the intestines and metabolized in the liver. The hepatocyte is considered a major site for metabolism of inorganic arsenic. Biomethylation is a major metabolic pathway for inorganic arsenic in humans and other mammalian species, and the compounds are metabolized to yield mono- and dimethylated metabolites. The pathways for transport and metabolism of arsenic are complex and not completely clear. In this study, we used uptake and cytotoxicity assays to investigate whether OATP-C can transport arsenic.

First, the transport of arsenic was characterized by the uptake study we used. After various forms of arsenic were added to the culture medium, we found that OATP-C could increase uptake of As ${ }^{\text {III }}$ and $\mathrm{As}^{\mathrm{V}}$, but not of $\mathrm{MMA}^{\mathrm{V}}$ and $\mathrm{DMA}^{\mathrm{V}}$ (Figure 3). These results suggest that inorganic arsenic can be transported by OATP-C. We compared relative toxicities of $\mathrm{As}^{\mathrm{III}}, \mathrm{As}^{\mathrm{V}}, \mathrm{MMA}^{\mathrm{V}}$ and $\mathrm{DMA}^{\mathrm{V}}$ in control and OATP-C-transfected cells using the MTT assay. Based on those results, the $\mathrm{LC}_{50}$ of $\mathrm{As}^{\mathrm{III}}$ and $\mathrm{As}^{\mathrm{V}}$ in HEK-Co cells were shown to be about twice those in HEK-OATP-C cells (Table 1). The difference in cytotoxicity was diminished by rifampin and taurocholic acid (Figure 4). However, in the present of substrates of OATP-C, inorganic arsenic was more toxic to HEK-Co cells without substrates. It is may be that

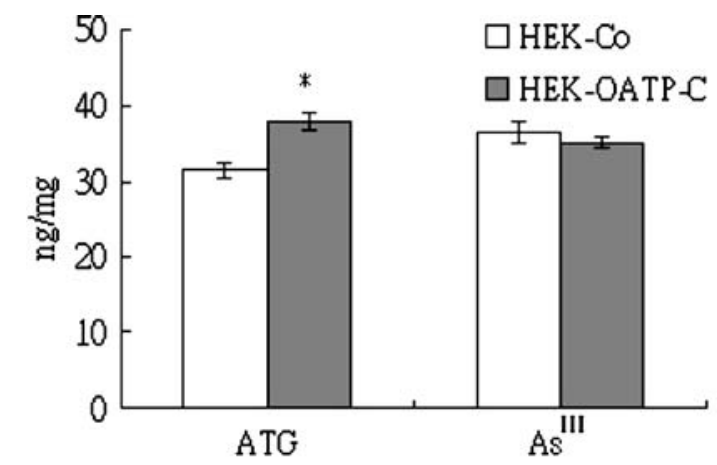

Figure 5. Uptake of $\mathrm{As}^{\mathrm{III}}$ and $\mathrm{As}(\mathrm{GS})_{3}$ in HEK-Co and HEK-OATP-C cells. The cells suspended in KRH buffer. Uptake of $A s^{\text {III }}$ or $\mathrm{As}(\mathrm{GS})_{3}$ for $1 \mathrm{~h}$ at the concentration of $10 \mu \mathrm{M}$ and at $37^{\circ} \mathrm{C}$. The results are shown as mean $\pm \mathrm{SD}$ $(n=3) .{ }^{*} p<0.05$, significantly different from HEK-Co. rifampin and taurocholic acid have some cytotoxicity. In contrast, there was no statistical difference in the $\mathrm{LC}_{50}$ of $\mathrm{MMA}^{\mathrm{V}}$ and $\mathrm{DMA}^{\mathrm{V}}$ between HEKOATP-C and HEK-Co cells (Table 1). The cytotoxicities of $\mathrm{MMA}^{\mathrm{V}}$ and $\mathrm{DMA}^{\mathrm{V}}$ are low and not affected by OATP-C transfection. Thus, MMA ${ }^{\mathrm{V}}$ and DMA ${ }^{\mathrm{V}}$ are not substrates of OATP-C.

On the other hand, results of cytotoxicity assays revealed the following order of cellular toxicity: arsenite $>$ arsenate $>\mathrm{DMA}^{\mathrm{V}}>\mathrm{MMA}^{\mathrm{V}}$. It has been reported that arsenite is more toxic than arsenate. However, there is controversy in the literature concerning the toxicity of $\mathrm{MMA}^{\mathrm{V}}$ and $\mathrm{DMA}^{\mathrm{V}}$. It has been shown that $\mathrm{MMA}^{\mathrm{V}}$ is more toxic than DMA ${ }^{\mathrm{V}}$ in V79 cells [35], but $\mathrm{DMA}^{\mathrm{V}}$ is more toxic than $\mathrm{MMA}^{\mathrm{V}}$ in $3 \mathrm{~T} 3$ cells [36]. In our study, $\mathrm{DMA}^{\mathrm{V}}$ was more toxic than $\mathrm{MMA}^{\mathrm{V}}$, but not as toxic as inorganic arsenic.

It is well recognized that $\mathrm{As}^{\mathrm{III}}$ is more toxic than $\mathrm{As}^{\mathrm{V}}$ in vitro and in vivo [35, 37]. GSH can reduce $\mathrm{As}^{\mathrm{V}}$ to $\mathrm{As}{ }^{\mathrm{III}}$ [38]. In the presence of reduced $\mathrm{GSH}$, arsenite conjugates with three molecules of glutathione to form ATG. The monomethyl metabolite of arsenic conjugates with two equivalents of glutathione to form methylarsenic diglutathione (MADG) [27, 39]. The dimethyl metabolite of arsenic conjugates with one equivalent of glutathione to form dimethylarsenic glutathione (DMAG) [39, 40]. Previous study showed that ATG and MADG, but not DMAG, is transported out of hepatocytes via the MRP2/ cMOAT transporter [27]. MRP1 is known to pump out inorganic arsenic as a tri-GSH conjugate at the basolateral membrane [25, 26].

In Table 1 and Figure 3, results indicate that OATP-C can take up inorganic arsenic, but we did not know what form of inorganic arsenic was transported by OATP-C. It could have been inorganic arsenic only or inorganic arsenic-GSH conjugates. Therefore, we examined which was the substrate of OATP-C by another uptake system, one in which cells were suspended in KRH buffer. We found that OATP-C can transport ATG but not $\mathrm{As}^{\mathrm{III}}$ (Figure 5). Our data suggest OATP-C transports As ${ }^{I I I}$ in a GSH-dependent (GSHconjugated) manner. However, the increase in uptake of inorganic arsenic was not as great as that of $\mathrm{E}_{2} 17 \beta \mathrm{G}$. In fact, the presence of ATG in the aqueous solution is unstable, so probably some dissociation of ATG occurred. It is possible that As-GSH conjugates are not stable in the buffer 
system, and thus OATP-C cannot transport them. In addition, in mammalian cell models, MRP1 has been shown to confer resistance to arsenite $\left(A s^{\mathrm{III}}\right)$ and arsenate $\left(\mathrm{As}^{\mathrm{V}}\right)$ in a GSH-dependent manner [26]. OATP-C can increase cellular uptake of $\mathrm{As}^{\mathrm{V}}$ in culture medium. It is possible that some GSH was present in the culture medium and that GSH can reduce $\mathrm{As}^{\mathrm{V}}$ to $\mathrm{As}{ }^{\mathrm{III}}$ so the arsenic conjugates with GSH. It has been reported that estradiol-17 $\beta$ D-glucuronide $\left(\mathrm{E}_{2} 17 \beta \mathrm{G}\right)$ and taurocholic acid are specific substrates of the OATP-C transporter. There was an approximately 10 -fold increase of $\left[{ }^{3} \mathrm{H}\right]-\mathrm{E}_{2} 17 \beta \mathrm{G}$ or $\left[{ }^{3} \mathrm{H}\right]$-taurocholic acid uptake in OATP-C-transfected cells compared with control cells (Figure 2). However, in the arsenic uptake and cytotoxicity assay, the OATP-C increased uptake and cytotoxicity of arsenic was not as much as that of $\mathrm{E}_{2} 17 \beta \mathrm{G}$. It is possible that there are other pathways for arsenic uptake by cells other than OATP-C [28, 29, 41]. For example, Hung and Lee [41] indicated that $\mathrm{As}^{\text {III }}$ can be freely taken up by cells through simple diffusion, and $\mathrm{As}^{\mathrm{V}}$ shares a common transport system with phosphate in cells. On the other hand, recent reports have shown that AQP9 and AQP7 can cause uptake of arsenite into mammalian cells [28].

In summary, transfection of OATP-C increased uptake of inorganic arsenic, and increased cytotoxicity of inorganic arsenic in the MTT assay. The mechanism for OATP-C transport of inorganic arsenic was in a GSH-dependent manner. Thus, we suggest that OATP-C may not be the major pathway for arsenic uptake, but rather, it has an auxiliary role in arsenic disposition.

\section{Acknowledgements}

The study is supported by grants NSC91-3112B006-004 and NSC92-3112-B006-016 from National Science Council of Republic of China (Taipei, Taiwan).

\section{References}

1. Meier P.J. and Stieger B., Bile salt transporters. Annu. Rev. Physiol. 64: 635-661, 2002.

2. Yabuuchi H., Tamai I., Morita K., Kouda T., Miyamoto K., Takeda E. and Tsuji A., Hepatic sinusoidal membrane transport of anionic drugs mediated by anion transporter Npt1. J. Pharmacol. Exp. Ther. 286: 1391-1396, 1998.
3. Kullak-Ublick G.A., Hagenbuch B., Stieger B., Schteingart C.D., Hofmann A.F., Wolkoff A.W. and Meier P.J., Molecular and functional characterization of an organic anion transporting polypeptide cloned from human liver. Gastroenterology 109: 1274-1282, 1995.

4. Suzuki H. and Sugiyama Y., Transport of drugs across the hepatic sinusoidal membrane: sinusoidal drug influx and efflux in the liver. Semin. Liver. Dis. 20: 251-263, 2000.

5. Abe T., Kakyo M., Tokui T., Nakagomi R., Nishio T., Nakai D., Nomura H., Unno M., Suzuki M., Naitoh T., Matsuno S. and Yawo H., Identification of a novel gene family encoding human liver-specific organic anion transporter LST-1. J. Biol. Chem. 274: 17159-17163, 1999.

6. Abe T., Kakyo M., Sakagami H., Tokui T., Nishio T., Tanemoto M., Nomura H., Hebert S.C., Matsuno S., Kondo H. and Yawo H., Molecular characterization and tissue distribution of a new organic anion transporter subtype (oatp3) that transports thyroid hormones and taurocholate and comparison with OATP-C. J. Biol. Chem. 273: 22395-22401, 1998.

7. Bossuyt X., Muller M. and Meier P.J., Multispecific amphipathic substrate transport by an organic anion transporter of human liver. J. Hepatol. 25: 733-738, 1996.

8. Tamai I., Nezu J., Uchino H., Sai Y., Oku A., Shimane M. and Tsuji A., Molecular identification and characterization of novel members of the human organic anion transporter (OATP) family. Biochem. Biophys. Res. Commun. 273: 251-260, 2000.

9. Tamai I., Nozawa T., Koshida M., Nezu J., Sai Y. and Tsuji A., Functional characterization of human organic anion transporting polypeptide B (OATP-B) in comparison with liver-specific OATP-C. Pharm. Res. 18: 1262-1269, 2001.

10. Tirona R.G., Leake B.F., Wolkoff A.W. and Kim R.B., Human organic anion transporting polypeptide-C (SLC21A6) is a major determinant of rifampin-mediated pregnane X receptor activation. J. Pharmacol. Exp. Ther. 304: 223-228, 2003.

11. Cui Y., Konig J., Leier I., Buchholz U. and Keppler D., Hepatic uptake of bilirubin and its conjugated by the human organic anion transporter SLC21A6. J. Biol. Chem. 276: 9626-9630, 2001.

12. Nordstrom D.K., Worldwide occurrences of arsenic in ground water. Science 296: 2143-2145, 2002.

13. Smith A.H., Lopipero P.A., Bates M.N. and Steinmaus C.M., Arsenic epidemiology and drinking water standards. Science 296: 2145-2146, 2002.

14. Chen C.J., Chuang Y.C., Lin T.M. and Wu H.Y., Malignant neoplasms among residents of a blackfoot disease-endemic area in Taiwan: high-arsenic artesian well water and cancers. Cancer Res. 45: 5895-5899, 1985.

15. Leonard A. and Lauwerys R.R., Carcinogenicity, teratogenicity and mutagenicity of arsenic. Mutat. Res. 75: 49-62, 1980.

16. Pinto S.S. and Nelson K.W., Arsenic toxicology and industrial exposure. Annu. Rev. Pharmacol. Toxicol. 16: 95-100, 1976.

17. Niu C., Yan H., Yu T., Sun H.P., Liu J.X., Li X.S., Wu W., Zhang F.Q., Chen Y., Zhou L., Li J.M., Zeng X.Y., Ou Yang R.R., Yuan M.M., Ren M.Y., Gu F.Y., Cao Q., Gu B.W., Su X.Y., Chen G.Q., Xiong S.M., Zhang T.D., Waxman S., Wang Z.Y., Chen Z., Hu J., Shen Z.X. and Chen S.J., Studies on treatment of acute promyelocytic 
leukemia with arsenic trioxide: remission induction, followup, and molecular monitoring in 11 newly diagnosed and 47 relapsed acute promyelocytic leukemia patients. Blood 94: 3315-3324, 1999.

18. Soignet S., Maslak P., Wang Z.G., Jhanwar S., Calleja E., Dardashti L.J., Corso D., DeBlasio A., Gabrilove J., Scheinberg D.A., Pandolfi P.P. and Warrell R.P. Jr., Complete remission after treatment of acute promyelocytic leukemia with arsenic trioxide. New Engl. J. Med. 339: 1341-1348, 1998.

19. Fischer A.B., Buchet J.P. and Lauwerys R.R., Arsenic uptake, cytotoxicity and detoxification studied in mammalian cells in culture. Arch. Toxicol. 57: 168-172, 1985.

20. Moore M.M., Harring-Brock K. and Doerr C.L., Relative genotoxic potency of arsenic and its methylated metabolites. Mutat. Res. 386: 279-290, 1997.

21. Sakurai T., Kaisc T. and Matsubara C., Inorganic and methylated arsenic compounds induce cell death in murine macrophages via different mechanisms. Chem. Res. Toxicol. 11: 273-283, 1998

22. Buchet J.P., Lauwerys R. and Roels H., Comparison of the urinary excretion of arsenic metabolites after a single oral dose of sodium arsenite, monomethylarsonate, or dimethylarsinite in man. Int. Arch. Occup. Environ. Health 48: 7179, 1981.

23. Carlin A., Shi W., Dey S. and Rosen B.P., The ars operon of Escherichia coli confers arsenical and antimonial resistance. J. Bacteriol. 177: 981-986, 1995.

24. Ji G. and Silver S., Reduction of arsenate to arsenite by the ArsC protein of the arsenic resistance operon of Staphylococcus aureus plasmid pI258. Proc. Natl. Acad. Sci. USA 89: 9474-9478, 1992.

25. Zaman G.J., Lankelma J., van Tellingen O., Beijnen J., Dekker H., Paulusma C., Oude Elferink R.P., Baas F. and Borst P., Role of glutathione in the export of compounds from cells by the multidrug-resistance-associated protein. Proc. Natl. Acad. Sci. USA 92: 7690-7694, 1995.

26. Leslie E.M., Haimeur A. and Waalkes M.P., Arsenic transport by human multidrug resistance protein 1 (MRP1/ ABCC1). J. Biol. Chem. 279: 32700-32708, 2004.

27. Kala S.V., Neely M.W., Kala G., Prater C.I., Atwood D.W., Rice J.S. and Lieberman M.W., The MRP2/cMOAT transporter and arsenic-glutathione complex formation are required for biliary excretion of arsenic. J. Biol. Chem. 275: 33404-33408, 2000.

28. Liu Z., Shen J., Carbrey J.M., Mukhopadhyay R., Agre P. and Rosen B.P., Arsenite transport by mammalian aquagoyceroporins AQP7 and AQP9. Proc. Natl. Acad. Sci. USA 99: 6053-6058, 2002.
29. Liu Z., Carbrey J.M., Agre P. and Rosen B.P., Arsenic trioxide uptake by human and rat aquaglyceroporins. Biochem. Biophys. Res. Commun. 316: 1178-1185, 2004.

30. Zalups R.K. and Barfuss D.W., Renal organic anion transport system: a mechanism for the basolsteral uptake of mercury-thiol conjugates along the pars recta of the proximal tubule. Toxicol. Appl. Pharmacol. 182: 234-243, 2002.

31. Li L., Lee T.K., Meier P.J. and Ballatori N., Identification of glutathione as a driving force and leukotriene $\mathrm{C} 4$ as a substrate for oatp1, the hepatic sinusoidal organic solute transporter. J. Biol. Chem. 273: 16184-16191, 1998.

32. Li L., Lee T.K., Meier P.J. and Ballatori N., Oatp2 mediates bidirectional organic solute transport: a role for intracellular glutathione. Mol. Pharmacol. 58: 335-340, 2000.

33. Cui Y., Konig J., Leier I., Buchholz U., Spring H. and Keppler D., Drug resistance and ATP-dependent conjugate transport mediated by the apical multidrug resistance protein, MRP2, permanently expressed in human and canine cells. Mol. Pharmacol. 55: 929-937, 1999.

34. Cui Y., Konig J., Nies A.T., Pfannschmidt M., Hergt M., Franke W., Alt W., Moll R. and Keppler D., Detection of the human organic anion transporters SLC21A6 (OATP-C) and SLC21A8 (OATP8) in liver and hepatocellular carcinoma. Lab. Invest. 83: 527-538, 2003.

35. Eguchi N., Kuroda K. and Endo G., Metabolites of arsenic induced tetraploids and mitotic arrest in cultured cells. Arch. Environ. Contam. Toxicol. 32: 141-145, 1997.

36. Ochi T., Kaise T. and Oya Ohta Y., Glutathione plays different roles in the induction of the cytotoxic effects of inorganic and organic arsenic compounds in cultured BALB/c 3T3 cells. Experientia 50: 115-120, 1994.

37. Styblo M., Del Razo L.M., Vega L., Germolec D.R., LeCluyse E.L., Hamilton G.A., Reed W., Wang C., Cullen W.R. and Thomas D.J., Comparative toxicity of trivalent and pentavalent inorganic and methylated arsenicals in rat and human cells. Arch. Toxicol. 74: 289-299, 2000.

38. Nemeti B. and Gregus Z., Reduction of arsenate to arsenite in hepatic cytosol. Toxicol. Sci. 70: 4-12, 2002.

39. Scott N., Hatlelid K.M., Mackenzie N.E. and Carter D.E., Reactions of arsenic (III) and arsenic (V) species with glutathione. Chem. Res. Toxicol. 6: 102-106, 1993.

40. Delnomdedieu M., Basti M.M., Otvos J.D. and Thomas D.J., Reduction and binding of arsenate and dimethylarsinate by glutathione: a magnetic resonance study. Chem. Biol. Interact. 90: 139-155, 1994.

41. Hung R.N. and Lee T.C., Cellular uptake of trivalent arsenite and pentavalent arsenate in KB cells cultured in phosphate-free medium. Toxicol. Appl. Pharmacol. 136: 243-249, 1996 